\title{
Review
}

\section{Relevant traits, genetic variation and breeding strategies in early silage maize}

\author{
Y Barrière $^{1^{*}}$, O Argillier ${ }^{1}$, B Michalet-Doreau $^{2}$, Y Hébert $^{1}$, \\ E Guingo ${ }^{1}$, C Giauffret $^{3}$, JC Émile ${ }^{1}$ \\ 'Station d'amélioration des plantes fourragères, Inra, 86600 Lusignan, France \\ ${ }^{2}$ Station de recherche sur la nutrition des herbivores, Inra, 63122 Theix, France \\ ${ }^{3}$ Station d'amélioration des plantes, Inra, 80200 Estrées-Mons, France
}

(Received 20 October 1997 ; accepted 24 December 1997)

\begin{abstract}
Summary - A silage maize hybrid is now considered different from a grain maize hybrid. This paper gives data on relevant agronomic and feeding value traits suitable in a silage hybrid. It also gives data on breeding strategies and genetic variations available to maize breeders. A silage hybrid should have a good and stable biomass yield, and a grain content between 46 and $50 \%$ according to the quantity and the quality of starch in the diet. Earliness of the plant should be adapted to the cropping area, and should be assessed from whole plant experiments. Cold tolerance should be improved to help cropping in northern areas, as well as resistance to soil fungi during the early growth of roots. A welldeveloped rooting system is necessary to either contribute to a good lodging resistance, or to contribute to a tolerance to water deficiency and nitrogen uptake. Protein content cannot be improved in the usual way, because of a lack of genetic variation, but improvement could be made through an investigation into the genetic variation of the degradability of proteins in the rumen. Digestibility should be investigated through an enzymatic solubility predicted from a NIRS calibration, performed on whole plant samples, allowing also an estimate of the cell-wall digestibility if NDF, starch and soluble carbohydrates were simultaneously given by NIRS calibrations. When available, a criterion of ingestibility should be used. The criteria of feeding value must be relevant to animal performances. To avoid the risk of a genetic drift towards low feeding values during stalk lodging resistance breeding, both traits must be considered simultaneously. Improved feeding value of a silage maize hybrid would also emerge after further investigations into biochemical traits in cell walls, in lignins monomeric composition and linkages between lignin and structural carbohydrates. Silage maize breeders must also take into account the need for feeding cattle at low costs and in environmentally friendly ways. (@ Inra/Elsevier)
\end{abstract}

\section{maize / silage / digestibility / ingestibility / breeding}

Résumé - Variabilité génétique, critères et stratégies de sélection des maïs ensilage précoces. L'objectif de ce texte est présenter une réflexion autour des caractéristiques de valeur alimentaire et de valeur agronomique à prendre en considération pour la sélection de maïs ensilage spécifiques de cette utilisation, en prenant en compte la variabilité génétique disponible et les stratégies de sélection à employer. Un maïs ensilage doit avoir un bon niveau de productivité, mais surtout une productivité stable au travers des différentes conditions de milieux. Sa teneur en grain doit se situer entre $46 \%$ and $50 \%$ selon la quantité et la qualité de l'amidon apporté par les compléments de la ration. Sa précocité en plante entière sera adaptée à la zone de culture envisagée, et un poids important sera donné à la tolérance au froid en début et fin de végétation, sans oublier la résistance aux champignons du sol exacerbant les dégâts de froid. La résis-

Article communicated by André Gallais (Gif-sur-Yvette)

* Correspondence and reprints

Tel: (33) 05495560 32; fax: (33) 05495560 44; e-mail: barriere@lusignan.inra.fr 
tance à la verse en végétation du maïs ensilage sera prise en compte à partir de qualités mécaniques des tiges, mais aussi à partir d'étude de la qualité de l'ancrage racinaire. L'amélioration du système racinaire devrait aussi conduire à des génotypes valorisant mieux les intrants et plus tolérants au déficit hydrique. En raison de la très faible variabilité génétique pour la teneur en protéines, l'amélioration de la valeur azotée de ce fourrage devrait être abordée au niveau de la variabilité de la dégradabilité ruminale de ces protéines. La sélection sur la valeur alimentaire comprendra une mesure de digestibilité de la plante entière, avec l'utilisation d'une solubilité enzymatique prédite en Nirs, une mesure digestibilité des parois estimée avec un critère de type IVDNSC (en français Dinag), et à terme une prédiction de l'ingestibilité. Les critères de valeur alimentaire utilisés devront être validés par des essais avec des animaux. Pour éviter des risques de dérive sur un caractère ou sur l'autre, la pression de sélection pour la résistance à la verse sera simultanée à ces mesures de valeur alimentaire. Parce que les interactions génotypes $\times$ milieux pour la digestibilité sont faibles, les estimations pourront être conduites dans un nombre limité d'environnements représentatifs. Des progrès en valeur alimentaire du maïs ensilage viendront aussi de ceux réalisés dans la compréhension de la variabilité de composition monomérique de constitution des lignines et de celle des liaisons entre lignines et glucides pariétaux. Les sélectionneurs de maïs ensilage devront aussi prendre en compte les contraintes environnementales et la nécessité de pouvoir alimenter les troupeaux au plus faible coût. À ce titre, et puisque, dans un milieu donné, c'est la valeur du génotype qui conditionne pour l'éleveur la valeur de l'ensilage, pouvoir mettre sur le marché des hybrides ayant une génétique « maïs ensilage » est une priorité pour les obtenteurs. (@ Inra/Elsevier)

maïs / ensilage / digestibilité / ingestibilité / sélection

\section{INTRODUCTION}

Silage maize expanded rapidly in northern Europe after the release of the first early flint-dent grain hybrids such as Inra258 and then LG11 which were more tolerant to low temperatures than the Wisconsin hybrids used previously. Approximately 3500000 ha are presently cropped for silage making in northern Europe, whereas the area used for silage making in southern Europe is only about 300000 ha. Maize silage is a reliable roughage with a high energy content, easy to produce, to ensile, to preserve and readily eaten by animals, especially by dairy cattle. But a silage maize must also fit in with the cropping practices, lowering inputs, pollution and silage production costs. The expected qualities and requirements of silage hybrids are clearly not identical to those of hybrids used in grain production. Based both on published data and on our own work, as well as on farmers' expectations and cattle feeding requirements, it is now possible to outline the relevant agronomic, feeding values and environmental traits for forage maize breeding in northern Europe, and to demonstrate ways of achieving this.

\section{SILAGE MAIZE YIELD AND EARLINESS}

The potential yield of cultivars presently registered as early silage hybrids is close to $18 \mathrm{t} / \mathrm{ha}$, with a dry matter content higher or equal to $30 \%$. Since the plants are harvested for silage before grain ripening, it is therefore possible, in a given location, to grow somewhat later genotypes for silage than those grown for grain. Even if the ensiling of maize is possible in a wider range of dry-matter content, the optimum dry-matter content of silage maize for animal feeding is usually between 30 and $35 \%$.

The French official assessment network CTPS of silage maize was set up in France in 1985, and it demonstrated noteworthy improvements in yield and earliness. Estimated from the best cultivars registered with the label 'fit for silage', the gain in biomass yield of hybrids reached $0.17 \mathrm{t} / \mathrm{ha}$ /year, during the past 11 years. Possibly because hybrids were simultaneously bred for grain yield, more than half this gain was due to an increase in the grain part, reaching around $0.10 \mathrm{t} / \mathrm{ha} / \mathrm{year}$, on average (Barrière et al, 1996; Lorgeou and Barrière, 1996). Then, a specialization in cultivars seemed to occur, since the genotypes with the largest increases in biomass were not systematically the same as those with the largest grain yields. The gains in grain yield for the best grain hybrids registered only for grain reached on average $0.12 \mathrm{t} / \mathrm{ha} / \mathrm{year}$. This comparison is, however, to be carefully considered, as not all hybrids were studied in grain and silage yield CTPS networks.

Further improvements in the yield of silage maize may be assumed, as actual yields are distinctly below the physiological limits of such a $\mathrm{C} 4$ species. Depending on the interception and photoconversion of light, under favourable northern environmental conditions, the theoretical limits of biomass yield may reach over $25 \mathrm{t} / \mathrm{ha}$. Thus, yield improvement in early hybrids will occur from a more efficient use of radiation. It may be achieved by improving the adaptation to higher plant densi- 
ties (Derieux et al, 1987), a slightly later flowering time, combined with a faster rate of leaf production and a faster rate of grain filling and ripening. Yield improvement will also occur from plants having a longer active photosynthetic capacity in less favourable environments, with a longer duration of photosynthetic activity in the leaves. Plants belonging to recent cultivars already have one extra internode and one extra leaf compared to older cultivars (Lorgeou and Barrière, 1996), and this trait will be of interest in silage maize hybrids.

Like the absolute productivity value, yield stability, at a high level, is an essential quality. A better tolerance to stress and a better recovery from environmental stress can be achieved, thus also allowing maize cropping in lower input conditions. Breeders have already made some progress in this way, as recent cultivars appeared hardier than older cultivars or populations (Tollenaar et al, 1994). Their superiority was even more obvious under difficult environmental conditions.

Similar breeding efficiency and improvements are expected for silage and grain yields, provided each whole plant trait involved is measured, and provided a suitable genetic variation in whole plant traits is available. Regarding whole plant yield, the effects of GCA (general combining ability) were preponderant, and the ratio between the variance of SCA (specific combining ability) and that of GCA was smaller than for grain yield (eg, Dhillon et al, 1990a; Geiger et al, 1992; Barrière et al, 1993a). This may relate to earlier and longer breeding for grain yield and earliness, than for biomass yield. The genetic resources available for silage maize improvements come from past eras of cropping and breeding grain maize. This germplasm is very diverse, including ecotypes, synthetics and lines, but it has been rarely investigated for its biomass traits. The combining ability in whole plant yield of flint and dent early lines commonly used in European breeding was proved noticeably better when crossed with 'Stiff Stalk'related lines (Barrière et al, 1993a). Medium-late or late elite lines can thus be powerful resources for biomass yield improvements of early silage maize. Because of these multiple heterotic patterns, medium-late or late hybrids can also be used to breed new lines for early silage maize, either by selfing after direct crossing or by back-crossing with early flint and dent lines.

The genetic pedigrees of most of the elite lines, which belong to private companies, are not known to us, and neither are the methodologies used in their creation. Nevertheless, the essential elite material seems to derive from pedigree breeding, using narrow base crosses between other elite lines as genetic resources, sometimes after a slight introduction of a 'foreign' or 'exotic' germplasm (Hallauer, 1990). Further progress is related to the soft integration of complex genetic systems, which control the environmental adaptability traits. Breeding based on elite germplasm is probably all the more essential since the elite performing in plants may greatly relate to epistatic effects. Molecular biology is a tool in clustering sources of diversity (Dubreuil et al, 1996), and pointing out the complementary management of lines to be used as progenitors in pedigree breeding. This could further be improved if these techniques were coupled with statistical methods allowing the identification of the source of genes to be used in reciprocal improvement of lines (Dudley, 1992) or allowing the prediction of single cross performances (Bernardo, 1996).

The breeding efficiency surely depends on the quality of the genetic material and on the efficiency of the methods used. It also depends on the quality of the trial, and of available environmental networks, being known for their discriminating powers regarding each agronomic trait and also regarding the homeostatic potential of the lines being bred.

\section{SILAGE MAIZE RESISTANCE TO ROOT LODGING}

Similarly to productivity and earliness, resistance to root lodging is a major aim in maize breeding for silage use. Lodging is due to a wind-induced swivelling of the plant base in wet soil conditions, with or without root breaking. Susceptibility, or resistance, depends on the quality of the root anchorage, on the interactions between the growth or the geometry of the roots, and the growth or mechanical behaviour of the above-ground part of the plant. Resistance also depends on the retardation of root and stalk senescence, and on the stiffness of the stalk.

Variation in the anchoring quality of the roots was related to the variation in the susceptibility to root lodging of hybrids (Andrew and Solanki, 1966; Musich et al; 1965; Pellerin et al, 1990; Hébert et al, 1990-92). The genetic variation regarding resistance to lodging occurred with a large variation of all traits related to the form and structure of the root system. It thus appeared that there was a link between resistance to lodging and the number of roots on upper internodes, the average diameter of primary roots, and the orientation 
of the growth of the roots in the soil. GCA effects of these root traits were preponderant (Hébert et al, 1992). The various traits involved balance each other out, with threshold effects, so that plants with different genetic mechanisms behave similarly in the field (Hébert et al, 1996, Guingo and Hébert, 1997). If the plant anchorage is very strong, the stalk must be flexible to avoid its breakage by the damping-down of the forces. An important role in lodging behaviour was often assigned to other features of the above-ground parts, but the results are diverse and contradictory, especially concerning the plant height and the height of ear insertion.

Since root lodging is uncertain, and could occur heterogeneously in a given field with adverse influences of neighbouring plots, and since numerous replicates of trials are expensive, breeders have been interested, for a long time now, in traits and methods for the indirect breeding of resistance. Overall traits related to root morphology have been used, such as i) weight of the clump after pulling out (Holbert and Kochler, 1924; Hayes and Johnson, 1939; Thompson, 1968), ii) the force necessary to pull a plant out vertically (Nass and Zuber, 1971; Arihara and Crosbie, 1982; Peters et al, 1982; Kerven and Hallauer, 1983; Fincher et al, 1985; Melchinger et al, 1986), or else iii) the intensity of the force when pushing plants laterally (Kushibiki, 1979; Koinuma et al, 1990; Fouéré et al, 1985). The relevance of these characters appeared rather limited in lodging resistance improvements, but these methods are probably not used often enough these days to offer a proper assessment.

Genetic resources in root lodging resistance are more easily found in late lines or hybrids than in early germplasm where this trait is more rare and often related to poor yielding. The breeding for stalk standability in the last 15 years was carried out by assessing the phenotypic resistance in greatly exposed environments. It made it possible to create extremely resistant early hybrids, recently registered in France. However, a lot of these very resistant cultivars had a poor or very poor feeding value. Conversely, cultivars bred for a good feeding value were often susceptible. This may be a random drift during breeding, either for feeding value or for lodging resistance traits. But these unwanted changes may also be due to negative pleiotropic effects or gene linkages, especially when breeding for stalk resistance to lodging, or to breaking at grain maturity. However, Melchinger et al (1986), Argillier et al, (1995), and Hébert et al (1996) have shown that there was no absolute linkage between standability and feed- ing value, on broad based germplasms. Different strategies in the distribution of structural materials in the stalk may bring about plants with improved mechanical resistance, with varying consequences on digestibility (Undersander et al, 1977; Hawk et al 1984; Pinheiro, 1984; Albrecht et al, 1986; Hébert et al, 1996). The understanding of what is conducive to resistance to root lodging and to good ingestibility or digestibility will thus make it possible to combine good resistance to lodging with high feeding values, both for silage cultivars and for dual purpose (grain and silage) cultivars. Five important QTL (quantitative trait loci) have been demonstrated for in-vitro digestibility (Carolo et al, 1996). QTL were also highlighted for traits of the root system (Guingo et al, 1997), while other QTL were investigated for resistance to lodging. The study of linkages between all these QTL will allow breeding for the two traits from non-antagonistic genetic systems.

\section{SILAGE MAIZE TOLERANCE TO COLD TEMPERATURES}

In early-flowering and early-ripening maize, grown in the northern part of Europe, the yield is mainly limited by the insufficient absorption of photosynthetically active solar radiation by the plant canopy. The maximum LAI (leaf area index) is reached during the cropping season when solar radiation has distinctly diminished. Moreover, this LAI value, near 3 , is not sufficient for a maximum interception efficiency. With low temperatures, foliation is delayed and the maximum LAI value may be decreased by $20 \%$. Among the characters determining foliation, the leaf elongation rate is the trait the most sensitive to temperature, and with the widest genetic variation. Tolerance to low temperatures may thus be defined as an aptitude of plants to grow under cooler conditions or their aptitude to recover their photosynthetic capacity soon after a cold stress. In a review, Greaves (1996) pointed out that numerous physiological factors were involved in tolerance to suboptimal temperatures in maize. Lower thermal thresholds for germination and early growth are requested, integrating all processes of inbibition, enzymatic breakdown of kernel reserve, cell division and extension. Plants may therefore have the ability to grow autotrophically at low temperature. The survival of young plants in cold climates depends very much on reduced cellular and tissue injuries in severe chilling conditions. Cellular damage to the roots, due to chilling injury, could also allow pathogenic attacks (Miedema et al, 1987). 
Messiaen (unpublished data, pers com) clearly pointed out that the susceptibility of maize plants to cold conditions was also related to their susceptibility to Pythium arrhenomanes-graminicola (Messiaen et al, 1977) and probably Fusarium roseum sp (Messiaen et al, 1976). Breeding for both cold and pathogen tolerance is necessary by carrying out, for example, comparative cold tests with or without fungi.

During the past 5 years, data in the understanding of true cold tolerance were obtained from the use of transgenic plants. The role of the lipids of chloroplast membranes (Murata et al, 1992; Somerville, 1995) and that of the detoxification systems of reactive forms of oxygen (Tsang et al, 1991; Gupta et al, 1993; Prasad et al, 1994) have been established.

Sources of variation for earliness and cold tolerance were first found in flint maizes of European origin (Lacaune particularly). But, for further improvement, the building up of an early silage maize ideotype, tolerant to cold and fit for cropping in the northern part of Europe, has to be based on other genetic resources. Some tropical ecotypes from highland areas $(2-3000 \mathrm{~m})$ displayed, under cold conditions, a faster seedling emergence, a better and faster developed leaf system, less chlorosis and a greater dry matter yield. Results obtained at Inra Mons strengthened those previously obtained (eg, Stamp, 1984; Sheldrick, 1980; Hardacre and Eagles, 1986; Eagles and Lothrop, 1994, quoted by Greaves, 1996). These ecotypes improved by CIMMYT, compared with plants from temperate regions, showed, after an early sowing at Mons (Somme), a sowingseedling emergence duration shortened by nearly $1-5 \mathrm{~d}$, a vegetation development greater by $10 \mathrm{~cm}$ at the 7-8 visible leaf stage, and a dry matter weight greater by nearly $5 \mathrm{~g}$ per plant at the beginning of July (Giauffret, unpublished data). As for the characters linked to the growth of young plants, additive effects were predominant, with little partial dominance (Eagles, 1988). Heritability of mean leaf appearance rate and of number of visible leaves $300^{\circ} \mathrm{C}$ days (base 6) after sowing were between 0.7 and 0.9 (Potier, 1982).

Most of these experiments were conducted with seedlings, but cold tolerance is also required during plant ripening. Chilling injury, due to a low temperature during the previous summer or at the beginning of autumn, has been related to earlier senescence, roots and stalk rot damages (Barrière et al, 1981). However, Newton and Eagles' (1991) results suggested that grain filling could be efficient at a lower temperature in highland germplasm, rather than in usual germplasm. But other results (Hardacre and Eagles, 1989; Ellis et al, 1992; Eagles and Lothrop, 1994) showed that the growth rate of highland germplasm was lower in seedlings or in adult plants than that of usual germplasm when exposed to favourable temperature conditions. A multi-trait breeding could, therefore, be achieved because the improvement of a single suboptimal tolerance trait does not modify the performance of genotypes in a temperature-limiting environment (Greaves, 1996). Cold hardiness in elite silage maize would therefore be obtained through breeding crosses between elite lines and highland and european tolerant lines, introgressing and piling up numerous multigenic traits originating from these unadapted and adapted germplasms

\section{USE OF INPUTS IN SILAGE MAIZE}

For a better control of environment protection, a silage maize ideotype could be a good growing plant in lower nitrogen conditions. Nitrogen leaching may occur in autumn and in winter before maize sowing, when no inter-crop was sown. Nitrogen leaching may also occur in spring, when the young maize needs are low. It may also occur during winter, after harvest, from the nitrogen residues due to poor fertilization managements, with too high spreading, and/or spreading at inappropriate times. Mineralization and nitrogen content of manures is often underestimated. Breeding for a better nitrogen use efficiency in silage maize is possible, since Bertin et al (1996) proved that there was a significant genotype $\times$ nitrogen fertilization interaction in maize grain yield. The best way to breed silage maize is no doubt to turn it into a plant capable of making good use of the nitrogen available in animal effluents. There is indeed a good adequation between the nitrogen mineralization period and the nutrient requirement period of the plants. When cattle are fed on a silage maize diet, the nitrogen (phosphorus and potassium) returns in the manure are about equal to the requirements of the maize crop. It is also worth noting that nitrogen rejects per cow are lower when cattle are fed silage maize instead of grass (Le Gall et al, 1996; van Keulen et al, 1996). Compared to the content of silage maize, which is closer to $8 \%$, a crude protein content nearing $10-11 \%$ would be well suited to the feeding of high-yielding dairy cows. A greater ability in maize to take up nitrogen originating from greatly available manures could lead to a higher nitrogen content of silage maize. For animal health reasons, 
and to avoid nitrogen volatilization, manure spreading on pasture is not desirable. Maize should be bred as a depollution and valorization tool for any available organic nitrogen in animal effluents.

The silage cropping maize zones are not where water resources are usually limiting. Even if the tolerance to stress is almost greater in the more recent genotypes, the improvement in plant behaviour during or after a period of hydric stress should be more specifically taken into account. The most plausible way in tolerance improvement is no doubt the aptitude to regrow faster after a stress period. A different approach is available through the use of the genetic variability of the root system. Variations in the uptake of water (and consequently nitrogen) by the plant are probably more related to variations in root growth than to the intrinsical uptake variations. Different studies proved that the morphology of the maize root system was variable, particularly the number of roots and ramifications, as well as the length of the roots. Plants having a more developed root system are more capable of finding water in deeper soils as well as extracting water when the water plant potential is lower. Therefore, such plants will resist longer hydric stress. The comparison of the root growth of maize and of sorghum was quite conclusive in this respect (Lemaire et al, 1996). More attention should be given by breeders to roots, as it would lead to an improvement in tolerance against water and nitrogen shortages, as well as in lodging resistance and in the yield stability of hybrids.

\section{OTHER AGRONOMIC TRAITS IN SILAGE MAIZE}

Breeders must take into account other agronomic traits, either explicitly or implicitly. The ability of hybrids to keep a stable yield across various environmental conditions is investigated through a multi-location trial network. The computing of stability indexes such as the ecovalences (Wricke, 1962) make the ranking of genotypes for that particular trait possible. Modern genotypes, apart from their distinctly better stalk standability, show a greater tolerance to stress than older genotypes, which is conducive to a greater stability (Tollenaar et al, 1994). The ability of plants to 'stay-green' during the ripening of the grain, is an indirect way of improving the yield, the mechanical qualities of the stalk and the disease tolerance during ripening. A stronger stay-green in silage maize hybrids could be less favourable because of a negative effect on the dry matter content of the stover. Possibly due to its tropical origin, maize is seldom seriously affected by pathogens when cultivated in northern Europe. An efficient selection against stalk rots (Fusarium sp) and corn smut (Ustilago maydis) has been performed for a long time. The arrival of tassel smut (Sphacelotheca reiliana), in the mid 1980s, forced the breeders to look at this disease resistance. In the areas where silage maize crops are infested, chemical treatments of the soil or the seed are available, but different cultivars that are both good performers and reasonably tolerant to the disease are already available. Apart from traditional genetic methods, the tolerance to the European corn borer (Ostrinia nubilalis) is managed through biological control with Bacillus thuringiensis, or by spraying its toxin. Maize hybrids, genetically modified with the Bt toxin gene, are also available, but their use should be carefully considered regarding the feeding use of the whole maize plant. Moreover, in northern Europe cropping areas, a silage maize crop would require very little phytosanitary treatments, and only for soil pest and weed control. Aerial fungicidal applications should not be considered.

\section{PROTEIN VALUE IN SILAGE MAIZE}

Maize silage has a poor protein content, which is readily and usually corrected by oil seed meals, probably all the more available as oil crops for industrial use is to expand. The useful protein supplements should remove the protein shortage in maize silage. They should also remove the shortage in limiting amino acids that often brings about an excess in crude protein, and, as a consequence, an excessive excretion of polluting nitrogen. Direct adding of amino acids in the diet is possible, for instance, for both methionine and lysine, but not for tryptophan, isoleucine and valine, which are not economically available after industrial synthesis.

Regarding the 126 early hybrids studied at Lusignan after a long-term experiment with standard sheep (see also Barrière et al, 1992), the average crude protein content $(\mathrm{N} \times 6.25)$ was equal to $8.2 \%$, the very early ones being $0.1 \%$ above and the medium-early $0.1 \%$ below. Crude protein content was independent of the energy value and of the grain content, but tended to be negatively linked to the biomass yield, according to the nitrogen dilution law $(r=-0.45)$. Such a tendency in negative relationships between crude protein and 
yield was also observed by Maggiore et al (1980) and by Gallais et al (1981). As the genetic variance was particularly small (0.11 including experimental hybrids with the same earliness), the narrow-sense heritability of crude protein content was very low, about 0.16 (Barrière et al, 1992). Expected progress in crude protein content of silage maize by traditional genetic methods would indeed be very limited.

The protein value of a feed in ruminants must in fact be expressed as amino acids absorbed from the small intestine, according to the new protein evalutation system (PDI, digestible protein in the small intestine, Andrieu and Demarquilly, 1987). The PDI value mainly depends on the crude protein content of the feed and on the crude protein degradability in the rumen. Variation in the ruminal degradability of crude protein in maize was recently demonstrated, and could range from 62 to $83 \%$ (Cabon and Chapoutot, 1996; von Keyserlingk et al, 1996). The part due to genetic variation in that phenotypic variation is not known. But, in order to assess the possible genetic improvement of the PDI values in silage maize, the genetic variation in protein degradability in the rumen should be investigated, from in-situ measurements with fistulated cows. This variation could probably be very significant, and justify a breeding effort.

\section{ENERGY VALUE, INTAKE IN SILAGE MAIZE FROM IN-VIVO MEASUREMENTS}

The feeding value of a forage is related to its ingestibility and its digestibility, and defines the energy supplied by the forage in an animal's diet. The variation in feeding value of a maize cultivar is related i) to the variation in digestibility of the stover part of the plant, ii) to the variation in grain content, iii) to the variations in ingestibility, and iv) to the digestive interactions between the forage and the concentrates in the diet. The digestibility of the cell-wall parts depends on the intrinsic characteristics of cell walls, which define their susceptibility to microbial degradation. It also depends on the efficiency of rumen micro-organisms, and on the duration of an attack by micro-organisms, which is related to the transit rate of the cell walls out of the rumen.

As a result of works first published in 1969 and 1974 by Demarquilly and Andrieu, the energy values for silage maize given in the Inra reference book for animal nutrition (Andrieu and Demarquilly, 1988) range between 0.90 and 0.96
UFL per kg dry matter, according to maturity and/or grain content (UFL is the French net energy feed unit, with $1 \mathrm{UFL}=7.11 \mathrm{MJ}$ ). These reference values were estimated about 30 years ago, with a limited number of early genotypes having a good feeding value (Inra258, Funk245, Dekalb204, LG11), which are not representative of the currently available hybrids. A lot of measurements undertaken at Inra Lusignan with standard sheep, on a much wider genetic basis have shown that the genetic variation in energy value of silage maize was much larger (273 hybrids, including 126 very early to medium-early hybrids registered in EU, but mostly in France, see also Barrière et al, 1992). In the 126 registered very early to medium-early studied varieties, the energy values ranged between 0.79 and 0.95 UFL (table I). Among these hybrids, $33 \%$ had an energy value below or equal to $0.88 \mathrm{UFL}$ and $40 \%$ above or equal to 0.90 UFL. The whole range of UFL values was present in each class of hybrid maturity, but there was only one very early hybrid with a value below 0.86 UFL, whereas $1 / 3$ of early and medium-early hybrids fell into this group. The narrow sense heritability of UFL energy value was high (0.85), making significant progress possible (Barrière et al, 1992).

The grain constitutes about $45 \%$ of the dry matter of the whole plant, and is almost completely digestible, whilst crude fibre constitutes only 20 $\%$. Moreover, the study of genetic correlations showed that the UFL value was more narrowly related to crude fibre digestibility $(r=0.77)$ than to grain content $(r=0.59)$. Effect of environment on in-vivo digestibility or on energy value was important. However, the genotype $x$ environment interactions were weak compared to the genotype effect (Argillier et al, 1997). Computed over 39 genotypes and 20 years of in-vivo measurements at Lusignan, and computed from a multilocation cropping of maize, the mean square of the effect of environment on energy value was 2-3 times as large as that of the genotype effect, but the latter was 9-16 times as large as the genotype $x$ environment interaction. Therefore, maize breeders are able to estimate energy value from a limited number of trials, provided the locations are well chosen, and provided a relevant in-vitro criterion is available.

The genetic variation in the energy value of silage was also proved in experiments with young bulls or dairy cows, even if maize is not the only constituent of the diet (Istasse et al, 1990; Ciba semences, 1990; Carpentier et al, 1995; Barrière et al, 1995a,b; Emile et al,1996). All other factors being equal, when comparing hybrids with poor or 
Table I. Variations in feeding value of early hybrids, registered in France, in Belgium (B) or in the Netherlands (NL), measured on standard sheep.

\begin{tabular}{lccccccccc}
\hline Hybrids & $\begin{array}{c}\text { Registered } \\
\text { in }\end{array}$ & Earliness & $\begin{array}{c}\text { Number } \\
\text { of silos }\end{array}$ & $\begin{array}{c}\text { DMO } \\
(\%)\end{array}$ & ic & $\begin{array}{c}\text { DCF } \\
(\%)\end{array}$ & ic & UFL \\
\hline Rh161 & 1989 & DP & 4 & 65.2 & 1.9 & 47.0 & 5.2 & 0.79 & 0.03 \\
Rh228 & 1994 & TP & 3 & 66.5 & 2.2 & 42.4 & 5.8 & 0.83 & 0.04 \\
Rh162 & 1990 & DP & 17 & 67.7 & 1.0 & 46.3 & 2.7 & 0.84 & 0.02 \\
Rh188 & 1989 & P & 4 & 68.8 & 1.9 & 52.4 & 5.1 & 0.86 & 0.03 \\
Rh247 & 1994 & P & 2 & 68.8 & 2.7 & 49.2 & 7.1 & 0.87 & 0.05 \\
Rh243 & $1995 \mathrm{~B}$ & TP - P & 2 & 69.0 & 2.7 & 43.6 & 7.1 & 0.89 & 0.05 \\
Rh207 & 1993 & TP & 7 & 70.3 & 1.5 & 57.0 & 4.0 & 0.90 & 0.03 \\
LG11 & 1970 & P & 74 & 70.8 & 0.5 & 52.8 & 1.3 & 0.90 & 0.01 \\
Rh185 & $1994 \mathrm{NL}$ & TP - P & 8 & 70.9 & 1.4 & 50.7 & 3.7 & 0.91 & 0.02 \\
Rh212 & 1994 & $\mathrm{P}$ & 6 & 71.2 & 1.6 & 50.4 & 4.3 & 0.92 & 0.03 \\
Dea & 1980 & DP & 32 & 71.3 & 0.7 & 52.7 & 2.0 & 0.91 & 0.02 \\
DK265 & 1987 & P & 11 & 71.3 & 1.2 & 54.5 & 3.1 & 0.91 & 0.03 \\
Rh246 & 1996 & TP & 2 & 71.3 & 2.7 & 59.3 & 7.1 & 0.91 & 0.05 \\
Brutus & 1978 & P & 6 & 71.6 & 1.6 & 54.6 & 4.3 & 0.91 & 0.03 \\
Rh254 & $1994 \mathrm{NL}$ & TP - P & 2 & 71.6 & 2.7 & 60.0 & 7.1 & 0.92 & 0.07 \\
Lixis & 1985 & P & 16 & 72.3 & 1.0 & 55.2 & 2.7 & 0.93 & 0.02 \\
Inra258 & 1958 & P & 44 & 72.6 & 0.6 & 58.0 & 1.5 & 0.93 & 0.01 \\
Rh174 & 1991 & TP & 4 & 72.8 & 1.9 & 49.3 & 3.5 & 0.93 & 0.03 \\
Rh263 & 1993 & DP & 2 & 73.4 & 3.7 & 55.7 & 7.1 & 0.95 & 0.05 \\
Rh167 & 1987 & DP & 8 & 73.5 & 1.4 & 51.1 & 3.7 & 0.95 & 0.02 \\
\hline & & & & & & & & &
\end{tabular}

Original data from Inra Lusignan digestibility assessments with sheep. DMO (organic matter digestibility), DCF (crude fibre digestibility) and UFL energy value for control hybrids and extreme hybrids in each class of earliness. TP $=$ very early, $P=$ early, $\mathrm{DP}=$ medium-early. $\mathrm{Rh}=$ registered hybrid, ic $=$ confidence limit at $P=0.05$, results obtained from less than four minisilos must be carefully considered).

good digestibilities in dairy cows, fat corrected milk yields differed from 1 to $3 \mathrm{~kg}$ among hybrids. The protein contents in milk were also equal or higher in hybrids, which allow greater milk yields. In a similar way, differences in average daily gains of young bulls reached $100 \mathrm{~g}$ per day among hybrids. With a voluntary intake of maize silage of about $16 \mathrm{~kg}$ of dry matter, the differences in production observed between extremes correspond to a difference in energy value of $0.12 \mathrm{UFL} / \mathrm{kg}$ of silage dry matter. Differences between extreme hybrids found in cows were slightly lower than when estimated with standard sheep.

Large differences in intake, greater than $1 \mathrm{~kg}$, were also demonstrated in experiments with dairy cows. The voluntary intake of the hybrid DK265 was greater than that of other hybrids (Barrière et al, 1995a). A better ingestibility was also shown by Ciba Semences in the kindred hybrids Briard and Bahia. Ingestibility and digestibility appeared to be partly independent. The digestibility of organic matter in DK265, Briard and Bahia was equal or lower than the digestibility in other hybrids such as Brutus or Inra258. A hybrid with a very good ingestibility, such as DK265, appeared less efficiently used by dairy cows, when supplying the usual supplements, since the excess in available energy was only partly converted into weight gain. The higher potential of such hybrids can only be expressed when the supply of energy supplements is lower, taking into account the extra intake of silage. The highly ingestible and digestible hybrids would be especially suitable for animal rearing in less intensive conditions. The same was also previously observed with the brown-midrib-3 hybrids, which also had high ingestibilities and digestibilities (Hoden et al, 1985).

Regarding breeding strategies, the same improvement in the energy content of the diet can be achieved from an increase in ingestibility of 1 $\mathrm{kg}$, or from an increase in energy value of 0.06 UFL per kg. Both traits should therefore be a breeding objective for the improvement of silage maize. However, very few hybrids or genetic resources are nowadays known for their higher ingestibility.

\section{CELL-WALL COMPOSITION IN SILAGE MAIZE}

Lignin content is obviously the major limiting factor of cell-wall digestibility. The digestibility of the stover part of a maize plant is determined by 
the amount and the distribution of lignified tissues in the stalk and leaves. But the biochemical composition of lignin, and the nature of hydroxy-cinnamic acids linked to it, are also involved (Hatfield, 1993; Jung and Deetz, 1993; Besle et al, 1994). Cell walls are mainly made up of fibrillar cellulose embedded in a matrix of phenolic constituents (lignins, cinnamic acids) and of hemicelluloses. Lignin consists mainly of guaiacyl and syringyl units, bound by ether linkages (such as $\beta$ O-4 linkages, broken by thioacidolysis) or carbon-carbon linkages (see Boudet et al, 1995). The two most frequent cinnamic acids are p-coumaric and ferulic acids, which could be linked to hemicelluloses and to lignin. Only ferulic acid however was proved to be covalently and simultaneously linked to lignin (by ether linkages) and to hemicelluloses (by ester linkages) (Lam et al, 1992).

Brown midrib mutants, with modified lignin contents and compositions, but also of low agronomic value, have been used and are still being used as models to study the relationship between lignification and feeding value (Barrière et al, 1993b; Chabbert et al, 1994). Recent data also pointed out that feeding values related to genetic variations existing in lignin content and composition of non-mutant hybrids (Jung and Buxton, 1994). The content in ferulic acid both etherified to lignin and esterified to hemicelluloses, and/or the condensation level of lignin estimated by the amounts of syringyl and guaiacyl monomers set free by thioacidolysis, could contribute to the variation in digestibility (Argillier et al, 1996a). There are thus several factors that affect the digestibility of cell walls, including lignin content, biochemical features of lignification and spatial distribution of lignified areas in plant tissues.

At least four enzymes are involved in the synthesis of cinnamylic alcohol during the lignification process (OMT, F5H, CCR, CAD) (see Boudet et al, 1995). Peroxydases and laccases are then involved in cinnamylic alcohol polymerization. Vignols et al (1995) proved that the bm3 mutations occurred in the gene encoding the OMT. For the building of a silage maize with good agronomic and feeding values, the complete or nil working systems such as the present bm3/OMT are probably not the most efficient. The use of the polymorphism of enzymes linked to lignification and the use of variations in the corresponding regulating genes will probably produce more interesting plants. Using strategies for the partial silencing of genes, with a sense or an anti-sense insertion, may also be another approach, perhaps more for comprehensive works, than for breeding works, due to potential risks and to the low acceptance of trans- genic plants by consumers. Bernard Vailhé (1995) and Bernard Vailhé et al (1996) had thus demonstrated with tobacco that the digestibility of cell walls increased after a transformation with $\mathrm{CAD}$ and OMT genes. The modifications affected more the composition than the content of lignin. The study of possible links between the QTL known for the feeding value, and the structural genes of the lignification enzymes would then lead to a study of the variability of these enzymes and the possible existence of different classes in each of them, as it was demonstrated in the OMT of tobacco (Herman et al, 1987; Pellegrini et al, 1993). Furthermore, these approaches would perhaps allow us to map out the regulating genes of these enzymes.

\section{GRAIN CONTENT AND GRAIN COMPOSITION IN SILAGE MAIZE}

Compared to the usual grassland forage plants, maize is different because it has a grain part and a stover part, whose sites of digestion are different in the animal. Cell walls are digested mainly in the rumen, while starch digestion, which is very high over the whole digestive tract, occurs partly in the rumen, and partly in the small and in the large intestine. The nature of the digestion products, and hence their metabolic use by the animal, depend on the site of starch digestion. Volatile fatty acids are produced in the rumen and in the large intestine, but glucose is produced in the small intestine. Moreover, in the rumen, the digestion of the grain starch does not occur independently of the cellwall digestion. If a large amount of starch is being digested in the rumen, whether it be from silage maize grain or from concentrates, a shift occurs in the balance of microbial populations. The amylolytic activity of the microbial ecosystem increases at the expense of the cellulolytic activity, leading to a reduced cell-wall digestion. The digestive interactions, the digestive products of starch, and then its efficiency, are related to its ruminal or intestinal site of digestion, which depends on the amount and ruminal degradability of maize and extra starch supplied in the diet and on the intrinsical ruminal degradability of starch in the unripe maize grain. The starch quantity and quality will have to be taken into account by maize breeders.

Silage maize breeders first need a criterion for grain content in maize. Experiments were therefore carried out at Inra Lusignan to find a suitable grain content for animal feeding. When ensiling large fields for cattle feeding, 1/4 of the ears were 
discarded from half the field. Silages with approximately $6 \%$ less grain were obtained, but with stover traits similar to those of control silages (Barrière and Emile, 1990; Emile and Barrière, 1992). Results proved that the two silages were used similarly either by cows or bulls, except when bulls were fed the hybrid Rh225, which was very poor in energy value and grain content. The optimal grain content could be around $46 \%$, corresponding to a starch content of about $30 \%$. This value would allow convenient milk yields and weight gains, but it would also obviously depend both on the complements supplied in the diet, and on the digestibility of the stover part. Within a disintensified cattle rearing, with a lower supply of concentrates and thus of extra starch, the optimal grain content in the maize silage could be higher nearing $50 \%$. Plant breeders will have to use simultaneously a criterion of grain or starch content and a criterion of stover digestibility.

Starch quality in silage maize may be a breeding topic. The ruminal part of starch digestion can be estimated by in-situ (Sauvant et al, 1994) or by in-vitro (Opatpatanakit et al, 1995) methods, and it was proved that, for a given grain ripeness, the ratio between maize starch digested in the rumen and in the intestine can vary considerably according to the maize genotype. Kotarski et al (1992) pointed out the effect of the quality of endosperm on the rate of degradation in cereal grains. Variations are mostly related in maize, whether the grain is flint or dent, according to the type of protein matrix in the endosperm and resulting in a more or less vitreous or floury albumen. Flint starch of maize was about $10 \%$ less degraded in the rumen than dent starch, and the rapidly degradable fraction was $50 \%$ smaller (MichaletDoreau and Champion, 1996). In a seven-hybrid trial, the in-situ ruminal dry matter degradation of immature maize grains ranged from $71.7 \%$ (dent endosperm) to $54.8 \%$ (flint endosperm), the grain degradation of the hybrid Dea nearing $56.1 \%$ (Verbic et al, 1995). A more systematic investigation of existing variations remains to be performed with grains of early hybrids, harvested at silage time, before silage maize breeders obtain and use a relevant criterion of starch degradability.

\section{IN-VITRO BREEDING CRITERION OF DIGESTIBILITY IN SILAGE MAIZE}

Regarding the feeding value traits of silage maize registered from 1958 onwards, the results are not as straightforward as the huge improvements in yield, earliness and stalk standability. This may be related to a genetic drift of traits that had not been taken into account during breeding, either the drift was random or was the consequence of negative linkages among traits. As Deinum and Struik (1985) proved in the Netherlands, Lorgeou and Barrière (1996) and Barrière and Argillier (1997) in France showed that there was a decrease in the average in-vivo feeding value of hybrids registered between 1958 and 1994. Across the years, the average decrease in DOM or UFL energy value arose mostly through the emergence of hybrids with poor feeding values. The poorest hybrids reached at least 0.11 UFL below the French reference value 0.90 UFL, while the higher energy values of newly registered hybrids did not go beyond 0.93 UFL, that is the energy value of old Inra258. However, during these years, no quality test was performed for an official registration in France.

For obvious practical and financial reasons, digestibility assessments have to be performed using in-vitro tests of dry matter, organic matter or cell-wall fraction digestibility. Rumen fluid or enzymes methods are available, either for research or for breeding purposes. In the Netherlands, van der Woude (1996) pointed out the improvement in in-vitro digestibility when using a feeding value criterion for hybrid registration. Breeders should therefore establish in France and in the EU, in agreement with the registration departments, feeding value rules for the official registration of silage maize, either for decisive use, or for informative use. But this approach would be pertinent only if the in-vitro method used was proved a good predictor of animal behaviour. The rules would also have to be improved as and when more information became available on prediction of intake.

For breeders, in large trial networks, a cheap and easy digestibility test has also to be devised on whole plant samples. But, when using solubilities on whole plant samples, a given digestibility value can be related to large grain or soluble carbohydrate contents, but with a low digestibility of cell walls, or from a high digestibility of the stover, with lower starch or soluble carbohydrate contents. Moreover, the digestibility of the stover part must be improved without modifying the starch content which has been found as optimal for the ruminant, and now set between 45 and $50 \%$, according to the supplements given. Breeding silage maize makes it therefore necessary to assess at the same time the digestibility of the whole plant, and the digestibility of the stover part. After Struik (1983), Dolstra and Medema (1990) used a computed digestibility of the cell walls (DCW) on stalk samples, assuming that all the non-NDF part 
was completely digestible. Argillier et al (1995, 1996b) have shown that it was possible to determine the digestibility of the non-starch, non-soluble carbohydrate part (IVDNSC) based on the enzymatic solubility of the whole plant (IVDMD, Ronsin, 1990) and on starch and soluble carbohydrate contents, assuming that starch and soluble carbohydrates were completely digestible.

Numerous works proved large genetic variations in the in-vitro digestibility of maize, either for whole plants or cell walls parts (eg, Gallais et al, 1976; Deinum and Bakker, 1981; Vattikonda and Hunter, 1982; Deinum et al, 1984; Deinum and Struik, 1985; Deinum, 1988; Dhillon et al, 1990b; Dolstra and Medema, 1990; Geiger et al, 1992; Hunt et al, 1992; Seitz et al, 1992; Dardenne et al, 1993; Dolstra et al, 1993; Wolf et al, 1993; Barrière et al, 1993a; Coors et al, 1994; Lundvall et al, 1994; Argillier et al, 1995). In early lines, according to Dolstra and Medema (1990), the stalk DCW best values were close to $50 \%$. Whole plant IVDNSC values in 175 lines of various origins, mostly early, but including some mediumlate, ranged between 59 and $72 \%$. IVDNSC in usual flint lines was around $63 \%$, and was around $60 \%$ in the dent lines (Argillier, 1995-96, unpublished data). Lines of superior feeding value are indeed available. Most of them are not used as parent lines of elite varieties, partly because they lead to poor-yielding hybrids or to hybrids susceptible to lodging. They can be used in breeding second cycle lines, and it will be all the more efficient as it will be possible to breed for the per se values (Argillier et al, 1995)

When considering the digestibility of whole plants, as well as stover, stalks or cell-walls, GCA effects for in-vitro values of digestibility were often preponderant over SCA effects. The ratios of GCA effects over SCA effects were also clearly higher for IVDNSC than for IVDMD, approximately 17 versus 12 (Argillier, 1995). Similary, genotype $\times$ environment interactions were often small compared to main effects. Broad-sense heritabilities of quality traits could be higher than 0.80 , but at least equal to those of yield (Coors et al, 1994). The heritability of IVDNSC was greater than that of IVDMD or of that of NDF digestibility. In the narrow sense it ranged between 0.45 and 0.65 , and in the broad sense between 0.75 and 0.70 (Argillier, 1995). With an usual $20 \%$ intensity of selection, with a heritability of the IVDNSC criterion equal to 0.55 , and knowing that the phenotypic mean square of the IVDNSC criterion was close to 25.0 for the early hybrids, the expected progress for the first selection cycle of breeding was of 2.1 points. Using the regression of Argillier et al (1996b) between UFL and IVDNSC, this progress was equivalent to an improvement of approximately 0.02 UFL, assuming plausibly there was no increase in NDF content.

The plant parts used for feeding value measurements must be carefully considered, especially when IVDNSC or DCW are computed, and assuming that all the non-NDF constituents are completely digestible. Comparisons made at Inra Lusignan pointed out that genotype ranking could be different, according to the cell-wall digestibility assessement which has been performed on stalk or whole plant samples. Bias could be related to the great variations in stalk carbohydrate content because the translocation of carbohydrates from the stalk to the ear may or may not have migrated to the ear at the time of sampling. They could also be related to variations in ratio and digestibility of cob and husks.

\section{IN-VITRO BREEDING CRITERION OF INGESTIBILITY IN SILAGE MAIZE}

Intake of silage maize affects as much as digestibility the supply of energy to cattle by a maize silage. Presently tests are available to breeders for the assessment of the agronomic and energy values, but no prediction tool is available for estimating hybrid ingestibility. The voluntary intake by standard sheep is not related to the intake by dairy cattle. Ingestibility can only be measured with the same sort of cattle, having similar yields in animal products (Demarquilly and Weiss, 1971; Chenost and Martin-Rosset, 1985; Moran et al, 1988; Dulphy et al, 1994). The regulation of the animal's appetite is above all a physical regulation. The filling capacity of maize silage, and hence its ingestibility, depends more on the rate of ruminal degradation of the cell-wall part than on the digestibility per se of this part. Insitu measurements of degradation kinetics on fistulated animals might provide a lead in the search of breeding criteria. The rate of NDF degradation between 0 and $36 \mathrm{~h}$ varies among genotypes (Inra Lusignan, Tovar et al, unpublished). Such a trait should be considered as being possibly related to a genotype's rumen-filling capacity, and as a consequence, to genotype ingestibility. Other traits may also be related to variations in ingestibility. Studies on the mechanical resistance of tissue to grinding could constitute an approach to finding genetical differences in friability, related to the ease of mastication and duration of rumination (Minson and Wilson, 1994). Differences in palata- 
bility among hybrids should exist, intrinsic to the genotypes or induced by silage fermentation. If present investigations have demonstrated very low digestibility values in some hybrids, the observed variation in ingestibility only showed an improvement over existing usual values, and, at the moment, no abnormally low values. This is also an a posteriori justification of the priority given to studies on digestibility. But, the improvement in the ingestibility of maize would probably also bring about an improvement in digestibility. The improvement of the palatability of tall fescue, by intra-specific selection or inter-specific hybridation, also brought about an improvement not only in its ingestibility, but also in its digestibility and its energy value (Emile et al, 1992; Ghesquière et al, 1996). However, mainly due to the fact that an in-vitro test is not yet available, the genetic resources for better ingestibility, to be introduced into a breeding programme, are not identified. As soon as a test can be made available, more systematic investigations in its variation could be performed between new and old lines, including ecotypes, making sure to discard any bias that may be due to variations in dry matter or in grain content.

\section{CONCLUSIONS}

The genetic diversification of maize from true grain types into dual grain and silage types or pure silage types has now started in Europe, and some seed companies have heavily invested in this. The feeding value of a maize silage in the field and in the silo is affected both by environment and genotype effects. The effects of the environment may be important, but the environment $\times$ genotype interactions are generally weak. As a consequence, in a given environment, the genotype determines for the farmer the value of the silage and hence the performance of his cattle. Breeding will be based on biomass yield and earliness of whole plants, with an emphasis on lodging resistance and a well developed root system. Breeding for feeding value will comprise efforts on the digestibility of the whole plant and cell walls, but also on voluntary intake. The relevance of in-vitro feeding value breeding criteria must obviously be controlled from experiments with animals. The relative weight to be put on yield and on digestibility is related to the economic conditions and to the type of animal (Utz et al, 1994). But hybrids whose energy value is below or equal to $0.88 \mathrm{UFL}$ (about $40 \%$ of current early hybrids, from Inra Lusignan data) should be discarded from 'silage maize' lists of registered cultivars. Silage maize breeders have also to take into account the need of feeding cattle at low costs and within environmentaly friendly ways.

Breeding would also be easier if the tests are of sound inheritance, and would allow us to sort out lines from their per se values. A criterion related to whole plant digestibility such as IVDMD could be used, but it would be better to use one related to cell-wall digestibility such as DCW or IVDNSC which are less linked to earliness effects. Starch content and quality must be taken into account. The optimal grain content in the silage should be adapted according to the amount and nature of the starches given in the diet. It can be assumed that a grain content lower than $40 \%$ will have negative effects in animal feeding, and that a value nearing $50 \%$ would be probably suitable for animals fed diets with high forage to concentrate ratios. A greater ability in maize to take up nitrogen from available effluents would have both ecological and nutritional advantages. Breeding for lodging resistance will be investigated simultaneously with the feeding value measurements, so as to avoid genetic drifts in either trait. Important improvements may be expected on cold tolerance. Input use and management must be reconsidered, even if the maize plant is already a very efficient one. New silage maize hybrids will soon be available, pointing out the diversity of breeding efforts on agronomic or feeding value traits.

Acknowledgements: The works carried out at Inra, Lusignan have had the support of Promais (CPSV and DINAG groups) and the support of the French Ministry of Agriculture (Contrats de Branche) and Ministry of Research (CPSV group). They have also been supported by the Poitou-Charentes Regional Council. Our thanks are due to JL Peyraud and L Delaby (Inra, 35590 Saint-Gilles) for their critical reading of the text. Thanks to A Charcosset, A Gallais (Inra, 91190 Le Moulon), P Brunschwig (IE, 49006 Angers), D Bloc, J Lorgeou, B Carpentier and JP Renoux (AGPM, 64121 Montardon) for their remarks, and thanks to PROMAIS breeders for their helpful discussions, especially those arising before and during the silage maize meeting of September 1996, in Nantes. Thanks to SEPROMA members (FR-75116 PARIS), especially G Camin, JP Muller, A Lacombe, JM Rivière and M Champion for their sound advices. Thanks also to SEPROMA for the financial support in the english translation, and thanks to A de Pourtalès for her english rereading.

\section{REFERENCES}

Albrecht KA, Martin MJ, Russel WA, Wedin WF, Buxton RD (1986) Chemical and in vitro digestible dry matter composition of maize stalks after selection for stalk strength and stalk rot resistance. Crop Sci 26, 1051-1055 
Andrew RH, Solanki JJ (1966) Comparative root morphology for inbred lines of corn as related to performance. Agron J 58, 415-418

Andrieu J, Demarquilly C (1987) Valeur nutritive des fourrages, tables et prévisions. Bull techn Inra CRZV Theix 70, 61-73

Andrieu J, Demarquilly C (1988) Valeur nutritive des fourrages, tables et prévisions. In: Alimentation des bovins, ovins et caprins (R Jarrige, Inra, ed), $471 \mathrm{p}$

Argillier O (1995) Relations entre verses, valeur alimentaire et productivité chez le maïs fourrage. Doctoral thesis, Ina-PG, $173 \mathrm{p}$

Argillier O, Barrière Y, Hébert Y (1995) Genetic variation and selection criteria for digestibility traits of forage maize. Euphytica 82, 175-184

Argillier O, Barrière Y, Lila M, Jeanneteau F, Gélinet K, Ménenteau V (1996a) Genotypic variation in phenolic components of cell walls in relation to the digestibility of maize stalks. agronomie 16, 123-130

Argillier O, Barrière Y, Hébert Y (1996b) DINAG, une estimation de la qualité de la partie non-grain du maïs ensilage sur des échantillons de plante entière. Symposium on Silage Maize (AGPM, IE, Inra, ITCF), Nantes, 17-18 September 1996, Poster, 447448

Argillier O, Barrière Y, Traineau R, Emile JC, Hébert $Y$ (1997) Genotype $\times$ environment interactions for digestibility traits in silage maize estimated from in vivo measurements with standards sheep. Plant Breeding 116, 423-427

Arihara J, Crosbie TM (1982) Relationships among seedling and mature root system traits of maize. Crop Sci 22, 1197-1202

Barrière Y, Panouillé A, Cassini R (1981) Relations source-puits et sélection du maïs pour la résistance à la pourriture des tiges. agronomie 1, 707-711

Barrière Y, Emile JC (1990) Effet des teneurs en grain et de la variabilité génétique sur la valeur énergétique du maïs ensilage mesurée par des vaches laitières. agronomie 10, 201-221

Barrière Y, Traineau R, Emile JC (1992) Variation and covariation of silage maize digestibility estimated from digestion trials with sheep. Euphytica 59, 6172

Barrière Y, Hébert Y, Julier B, Young E, Furstoss V (1993a) Genetic variation for silage and nirs traits in a half-diallel design of 21 inbred lines of maize. Maydica 38, 7-13

Barrière Y, Argillier O (1993b) Brown-midrib genes of maize: A review. agronomie 13, 865-876.

Barrière Y, Emile JC, Traineau R, Hébert Y (1995a) Genetic variation in the feeding efficiency of maize genotypes evaluated from experiments with dairy cows. Plant Breeding 114, 144-148

Barrière Y, Emile JC, Hébert Y (1995b) Genetic variation in the feeding efficiency of maize genotypes evaluated from experiments with fattening bulls. agronomie 15, 539-546
Barrière Y, Argillier O (1997) In vivo silage feeding value of early maize registered in France between 1958 and 1994. Euphytica (in press)

Boudet AM, Lapierre C, Grima-Petterati J (1995) Biochemistry and molecular biology of lignification. New Phytol 129, 203-236

Besle JM, Cornu A, Jouany JP (1994) Roles of structural phenylpropanoids in forage cell wall digestion. J Sci Food Agric 64, 171-190

Bernardo R (1996) Best linear unbiaised predictor of maize single cross performance. Crop Sci 36, 50-56

Bernard-Vailhé MA (1995) Influence de la qualité des lignines et acides phénols sur la dégradation des parois végétales dans le rumen - Etude de plantes transgéniques et normales. Doctoral thesis, université Blaise-Pascal, Clermont-Ferrand, $226 \mathrm{p}$

Bernard-Vailhé MA, Migné C, Cornu A, Maillot MP, Grenet E, Besle JM, Atanassova R, Martz F, Legrand M (1996) Effect of modification of the oMethyltransferase activity on cell wall composition, ultrastructure and degradability of transgenic tobacco. J Sci Food Agric 72, 385-391

Bertin P, Charcosset A, Gallais A (1996) Bases génétiques et physiologiques de l'efficacité d'utilisation de la fumure azotée chez le maïs grain. Symposium on Silage Maize (AGPM, IE, Inra, ITCF), Nantes, 17-18 September 1996, 363-370

Cabon G, Chapoutot P (1996) Relation entre la degradabilité ruminale de l'ensilage de maïs et la composition chimique des échantillons. Possibilités de prédiction. Symposium on Silage Maize (AGPM, IE, Inra, ITCF), Nantes, 17-18 September 1996, 381382

Camin G, Muller JP, Argillier O, Gouesnard B, Giauffret C (1996) Quel mais ensilage pour demain et pour l'avenir, le point de vue de chercheurs et de sélectionneurs. Symposium on Silage Maize (AGPM, IE, Inra, ITCF), Nantes, 17-18 September $1996,335-345$

Carolo P, Perret D, Blanchard P (1996) Sélection indirecte pour le rendement, la précocité et la valeur alimentaire du mais ensilage. Symposium on Silage Maize (AGPM, IE, Inra, ITCF), Nantes, 17-18 September 1996, Poster, 441-443

Carpentier B, Haurez P, Brauschwig Ph, Haurez Ph, Joulie M (1995) Valorisation par les jeunes bovins et les vaches laitières d'ensilages de maïs choisis pour leur digestibilité différente. Rencontre Recherche Ruminants, Institut de l'Élevage ed 2, 113-118

Chabbert B, Tollier MT, Monties B, Barrière Y, Argillier O (1994) Biological variability in lignification of maize. Expression of the brown-mirib bm3 mutation in three maize cultivars. $J$ Sci Food Agric $64,349-355$

Chenost M, Martin-Rosset W (1985) Comparaison entre espèces (mouton, cheval, bovin) de la digestibilité et des quantités ingérées des fourrages verts. Ann Zootech 34, 291-312 
Ciba-semences (1990) Valorisation laitière d'une variété de maïs en ensilage. Synthesis of an experimentation conducted by the EDE of Vendée during 1988-89-90, $13 \mathrm{p}$

Coors JG, Carter PR, Hunter RB (1994) Silage corn. In: Specialty Corns (AR Hallauer, ed), CRC Press, London, 305-340

Dardenne $\mathrm{P}$, Andrieu $\mathrm{J}$, Barrière $\mathrm{Y}$, Biston $\mathrm{R}$, Demarquilly $\mathrm{C}$, Femenias $\mathrm{N}$, Lila $\mathrm{M}$, Maupetit $\mathrm{P}$, Rivière F, Ronsin T (1993) Composition and nutritive value of whole maize plants fed fresh to sheep. 2. Prediction of the in vivo organic matter digestibility. Ann Zootech 42, 251-270

Deinum B, Bakker JJ (1981) Genetic differences in digestibility of forage maize hybrids. Netherlands. $J$ Agric Sci 29, 93-98

Deinum B, Steg A, Hof G (1984) Measurement and prediction of digestibility of forage maize in the Netherlands. Anim Feed Sci Technol 10, 301-313

Deinum B, Struik PC (1985) Improving the nutritive value of forage maize. In: Proceedings of the $13 t h$ Congress Maize and Sorghum Section of Eucarpia, Wageningen, the Netherlands, 9-12 September $1985,77-90$

Deinum B (1988) Genetic and environnemental variation in quality of forage maize in Europe. Netherlands. J Agric Sci 36, 400-403

Demarquilly C, Weiss P (1971) Liaisons entre les quantités de matière sèche de fourrage vert ingérées par les moutons et celles ingérées par les ovins. Ann Zootechn 20, 119-134

Derieux M, Darrigand M, Gallais A, Barrière $\mathrm{Y}$, Bloc Y, Montalant Y (1987) Estimation du progrès génétique réalisé chez le maïs grain en France entre 1950 et 1985. agronomie 7, 1-11.

Dhillon BS, Gurrath PA, Zimmer E, Wermke M, Pollmer WG, Klein D (1990a) Analysis of diallel crosses of maize for variation and covariation in agronomic traits at silage and grain harvest. Maydica $35,297-302$

Dhillon BS, Paul C, Zimmer E, Gurrath PA, Klein D, Polmer WG (1990b) Variation and covariation in stover digestibility traits in diallel crosses of maize. Crop Sci 30, 931-936

Dolstra O, Medema JH (1990) An effective screening method for genetic improvement of cell-wall digestility in forage maize. In: Proceedings of the 15th Congress Maize and Sorghum Section of Eucarpia, Baden, Austria, 4-8 June, 258-270

Dolstra O, Medema JH, de Jong AW (1993) Genetic improvement of cell-wall digestibility in forage maize (Zea mays L.). I. Performance of inbred lines and related hybrids. Euphytica 65, 187-194

Dubreuil P, Dufour P, Krejci E, Causse M, de Vienne D, Gallais A, Charcosset A (1996) Organization of RFLP diversity among inbred lines of maize representing the most significant heterotic group. Crop Sci 36, 790-799
Dudley JW, Saghai MA, Maroof, Rufener GK (1992) Information and selection of parent in corn breeding programs. Crop Sci 32, 301-309

Dulphy JP, Jouany JP, Martin-Rosset W, Thériez M (1994) Aptitudes comparées de différentes espèces d'herbivores domestiques à ingérer et digérer des fourrages distribués à l'auge. Ann Zootech 43, 11-32

Eagles HA (1988) Inheritance of emergence time at low temperature in segregating generations of maize. Theor Appl Genet 76, 459-464

Eagles HA, Lothrop JE (1994) Highland maize from central Mexico - its origin, characteristics and use in breeding program. Crop Sci 34, 11-19

Emile JC, Barrière Y (1992) Effets de la teneur en grain de l'ensilage de maïs sur les performances zootechniques des vaches laitières. Inra Prod Anim 5, 113 . 120

Emile JC, Gillet $\mathrm{M}$, Ghesquière $\mathrm{M}$, Charrier $\mathrm{X}$ (1992) Pâturage continu de fétuques élevées par des vaches laitières, amélioration de la production par utilisation de variétés sélectionnées pour l'appétibilité. Fourrages 130, 159-169

Emile JC, Barrière Y, Mauries M (1996) Effects of maize and alfalfa genotypes on dairy cow performances. Ann Zootch 45, 17-27

Ellis RH, Summerfield RJ, Edmeades GO, Roberts EH (1992) Photoperiod, temperature and the interval from sowing to tassel initiation in diverse cultivars of maize. Crop Sci 32, 1225-1232

Fincher RR, Darrah LL, Zuber MS (1985) Root development in maize as measured by vertical pulling resistance. Maydica 30, 383-394

Fouéré A, Pellerin S, Duparque A (1995) A portable electronic device for evaluating root lodging resistance in maize. Agron J 87, 1020-1024

Gallais A, Pollacsek M, Huguet L (1976) Possibilités de sélection du maïs en tant que plante fourragère. Ann Amélior Plantes 26, 591-605

Gallais A, Vincourt P, Huguet L (1981) Objectifs et critères de sélection du maïs fourrage. In: Proceedings of the Eucarpia-Maize and Sorghum Section, Montreux, Suisse

Geiger HH, Seitz G, Melchinger AE, Schmidt GA (1992) Genotypic correlations in silage maize. I Relationships among yield and quality traits in hybrids. Maydica 37, 95-99

Ghesquière M, Émile JC, Jadas-Hécart J, Mousset C, Traineau R, Poisson C (1996) First in vivo assessment of feeding value in Festulolium hybrids derived from Festuca arundinacea var. glaucescens and selection for palatability. Plant Breeding 115 , 238-244

Greaves JA (1996) Improving suboptimal temperature tolerance in maize - the search for variation. $J$ Exp Bot 47, 307-323

Guingo E, Hébert Y (1997) Relationships between mechanical resistance of the maize root system and 
root morphology, and their genotypic and environmental variations. Maydica 42, 265-274

Gupta AS, Heinen JL, Holaday AS, Burke JJ, Allen RD (1993) Increased resistance to oxidative stress in transgenic plants that overexpressed chloroplastic $\mathrm{Cu} / \mathrm{Zn}$ superoxide dismutase. Proc Natl Acad Sci USA 90, 1529-1533

Hallauer AR (1990) Methods used in developping maize inbreds. Maydica 35, 1-16

Hardacre AK, Eagles HA (1986) Comparative temperature reponse of corn belt dent and corn belt dent $x$ pool 5 maize hybrids. Crop Sci 26, 1009-1012

Hardacre AK, Eagles HA (1989) The temperature reponse of young hybrid maize plants adapted to different climates. New Zeal J Crop Horticultural Sci $17,9-17$

Hatfield RD (1993) Cell-wall polysaccharide interactions and degradability. In: Forage Cell-wall Structure and Digestibility (HG Jung, DR Buxton, RD Hatfield, J Ralph, eds), American Society of Agronomy, Madison, USA, 285-313

Hawk JA, Bergonsky WA, Pizzolato TD (1984) Morphological and anatomical characteristics of two corn synthetics recurrently selected for stalk crushing strength. Report of Annual Corn and Sorghum Research Conference (USA) 39, 84-97

Hayes HK, Johnson IJ (1939) The breeding of improved selfed lines of corn. J Am Soc Agron 31, $710-724$

Hébert Y, Duparque A, Pellerin S (1990) Verse en végétation: la variabilité génétique du système racinaire et de l'appareil aérien du maïs et ses conséquences pour la sélection. In: Physiologie et production du maïs. Pau (FRA) (D Picard, ed.) 1990/11/13-15, Association générale des producteurs de maïs, Paris, Versailles, 203-225

Hébert Y, Barrière Y, Bertholleau JC (1992) Root lodging resistance in forage maize: genetic variability of root system and aerial part. Maydica 37, 173-183

Hébert Y, Argillier O, Barrière Y (1996) Tolérance à la verse en végétation et caractéristiques de valeur alimentaire chez le maïs fourrage. Symposium on Silage Maize (AGPM, IE, Inra, ITCF), Nantes, 1718 September 1996, 355-362

Herman C, Legrand M, Geoffroy P, Fritig B (1987) Enzymatic synthesis of lignin: purification to homogeneity of the three O-methyltransferases of tobacco and production of specific antibodies. Archives of Biochemistry and Biophysics 253, 367376

Hoden A, Barrière Y, Gallais A, Huguet L, Journet M, Mourguet M (1985) Le maïs brown-midrib plante entière. III. Utilisation sous forme d'ensilage par des vaches laitières. Bull Tech CRZV Theix, Inra 60, 4358

Holbert JR, Kochler B (1924) Anchorage and extent of corn root systems. J Agron Res 27, 71-78

Hunt CW, Kezar W, Vinande R (1992) Yield, chemical composition, and ruminal fermentability of corn whole plant, ear, and stover as affected by hybrids. $J$ Prod Agric 5, 286-290

Istasse L, Gielen M, Dufrasne L, Clinquart A, Van Eenaeme C, Bienfait JM (1990) Ensilage de maïs plante entière, comparaison de 4 variétés. 2. Performances zootechniques. Landbouwtijdschrift Revue de l'Agriculture 43, 996-1005

Jung HJG, Deetz DA (1993) Cell-wall lignification and degradability. In: Forage Cell-wall Structure and Digestibility (HG Jung, DR Buxton, RD Hatfield, J Ralph, eds), American Society of Agronomy, Madison, USA, 315-346

Jung HJG, Buxton DR (1994) Forage quality variation among maize inbreds. Relationships of cell-wall composition and in vitro degradability for stem internodes. J Sci Food Agric 66, 313-322

Keyserlingk MAG von, Swift ML, Puchala R, Shelford JA (1996) Degradability of dry-matter and crude protein of forage in ruminants. Anim Feed Sci Technol 57, 291-311

Kerven TC, Hallauer AR (1983) Relation of vertical root-pull resistance and flowering in maize. Crop Sci $23,357-363$

Koinuma K, Inoue Y, Kato A (1990) Evaluation of lodging resistance of maize (Zea mays $\mathrm{L}$ ) by the measurement of the horizontal pull resistance. Bull Nat Grassl Res Inst 43, 23-29

Kotarsky SF, Waniska RD, Thurn KK (1992) Starch hybdrolysis by the ruminal microflora. $J$ Nur 122 , $178-190$

Kushibiki H (1979) A simple method of testing lodging resistance of maize. Bull Hok Pref Agric Exp Stn 42, 21-27

Lam TB, Iiyama TK, Store BA (1992) Cinnamic acid bridges betwenn cell wall polymers in wheat and phalaris internodes. Phytochemistry 31, 1179-1183

Le Gall A, Legarto J, Pflimlin A (1996) Systèmes fourragers laitiers et environnement, incidence de l'équilibre herbe maïs. Symposium on Silage Maize (AGPM, IE, Inra, ITCF), Nantes, 17-18 September 1996, 231-261

Lemaire G, Charrier X, Hébert Y (1996) Nitrogen uptake capacities of maize and sorghum crops in different nitrogen and water supply conditions. agronomie 16, 231-246

Lorgeou J, Barrière Y (1996) Le progrès génétique en maïs ensilage. Symposium on Silage Maize (AGPM, IE, Inra, ITCF), Nantes, 17-18 September 1996, 319-354

Lundvall JP, Buxton DR, Hallauer AR, George JR (1994) Forage quality variation among maize inbreds: in vitro digestibility and cell wall components. Crop Sci 34, 1672-1678

Maggiore T, Gentinetta E, Motto M, Perenzin M, Salamini F, Lorenzoni C (1980) Variability for protein and fibre content in three diallels of maize for silage production. In: Improvement of Quality Traits of Maize for Grain and Silage use (WG Pollmer, RH Phipps, eds), Pub Martinus Nijhoff, 135-153 
Melchinger AE, Geiger HH, Schmidt GA (1986) Vertical root pull resistance and its relationship to root lodging and forage traits in early maturing european inbred lines and F1 hybrids of maize. Maydica 31, 335-348

Miedema P, Post J, Groot P (1987) The effects of low temperature on seedling growth of maize genotypes. Agric Res Reports 926, Wageningen, Pudoc

Messiaen CM, Belliard-Alonzo L, Barrière Y, de la Tullaye B (1976) Étude qualitative des Fusarium roseum dans des sols des environs de Versailles sous diverses rotations et associations végétales. Ann Phytopathol 8, 269-281

Messiaen CM, Barrière Y, Belliard-Alonzo L, de la Tullaye B, Bouhot D (1977) Étude qualitative des Pythium dans quelques sols des environs de Versailles. Ann Phytopatol 9, 455-465

Michalet-Doreau B, Champion M (1996) Influence of maize genotype on rate of ruminal starch degradation. Ann Zootechn 44, 191

Minson DJ, Wilson JR (1994) Prediction of intake as an element of forage quality. In: Forage Quality, Evaluation and Utilisation (GC Fahey, ed), American Society of Agronomy, Inc, Crop Science Society of America, Inc, Soil Science Society of America, Madison, WI, 533-563

Moran JB, Lemerle C, Trigg TE (1988) The intake and digestion of maize silage-based by dairy cows and sheep. Anim Feed Sci Technol 20, 239-312

Murata N, Ishizaki-Nishizawa O, Higashi S, Hayashi H, Tasaka Y, Nishida I (1992) Genetically engineered alteration in the chilling sensitivity of plants. Nature 356, 710-713

Musich GJ, Fairchild ML, Fergason VL, Zuber NS (1965) A method of measuring root volume in corn (Zea mays L). Crop Sci 5, 601-602

Nass HG, Zuber MS (1971) Correlation of corn (Zea mays $\mathrm{L}$ ). Roots early in development to mature root development. Crop Sci 1 1, 655-658

Opatpatanakit Y, Kellaway RC, Lean IJ, Annison G, Kirby A (1995) Effects of cereal grains on fibre digestion in vitro. Aust J Agric Res 46, 403-413

Pellegrini L, Geoffroy P, Fritig B, Legrand M (1993) Molecular cloning and expression study of a new class of ortho-diphenol-O-methyl transferases induced in tobacco (Nicotinia tabacum L) leaves by infection of elicitor treatment. Plant Physiol 103, 509-517

Pellerin S, Trendel R, Duparque A (1990) Relation entre quelques caractères morphologiques et la sensibilité à la verse en végétation du maïs (Zea mays L). agronomie 6, 439-446

Peters DW, Shank DB, Nyquist WE (1982) Rootpulling resistance and its relationship to grain yield in F1 hybrids of maize. Crop Sci 22, $1112-1120$

Pinheiro MEVL (1984) Stover forage quality and stalk strength. Relationship in corn, Zea mays L. $\mathrm{PhD}$ diss, Iowa State Univ, Ames, IO
Potier F (1982) Étude de la variabilité génétique à l'intérieur d'une population de maïs adaptée aux basses températures. Mémoire de DEA, Inra Lusignan, $75 \mathrm{p}$

Prasad TK, Anderson MD, Martin BA, Stewart CR (1994) Evidence for chilling-induced oxidative stress in maize seedlings and regulatory role for hydrogen peroxyde. Plant Cell 6, 65-74

Ronsin T (1990) Use of NIRS prediction of digestibility in a breeding program for silage maize. In: Proceedings of the 15th Congress of Maize and Sorghum Section of Eucarpia, 4-8 June, Baden, Austria, 277-288

Sauvant D, Chapoutot P, Archimède H (1994) La digestion des amidons et ses conséquences. Prod Anim 7, 115-124

Seitz G, Geiger HH, Schmidt GA, Melchinger AE (1992) Genotypic correlations in silage maize. II Relationships between inbred lines and testcross performances. Maydica 37, 101-105

Sheldrick RD (1980) Selection of cold tolerant maize genotypes. In: Production and Utilization of the Maize Crop (ES Bunting, ed), Hereward and Stourdale Press, Ely, UK, 171-178

Somerville C (1995) Direct tests of the role of membrane lipid composition in low-temperature-induced photoinhibition and chilling sensitivity in plants and cyanobacteria. Proc Natl Acad Sci, USA 92, 62156218

Stamp P (1984) Emergence an seedling growth of tropical highland maize and its top crosses with middle European hybrids. Zeitchrift für Acker und Pflanzenbau 153, 116-121

Struik PC (1983) Physiology of forage maize (Zea mays $\mathrm{L}$.) in relation to its productivity. Doctoral thesis, Wageningen, $97 \mathrm{p}$

Thompson DL (1968). Field evaluation of corn root clumps. Agron J 60, 170-172

Tilley JMA, Terry RA (1963) A two stage technique for the in vitro digestion of forage crops. J Br Grassl Soc 18, 104-111

Tollenaar M, McCullough DE, Dwyer LM (1994) Physiological basis of the genetic improvement of corn. In: Genetic Improvement of Field Crops (GA Sflafer, ed), M Dekker Inc, 183-236

Tsang EWT, Bowler C, Hérouart D, Van Camp W, Villarroel R, Genetella C, Van Montagu M, Inzé D (1991) Differential regulation of superoxide dismutases in plants exposed to environmental stress. Plant Cell 3, 783-792

Undersander DJ, Bauman LF, Lechtenberg VL, Zuber MS (1977) Effect of cyclic selection for high and low crushing strength on rind, pith, and whole composition in corn. Crop Sci 17, 732-734

Utz HF, Melchinger AE, Seitz G, Mistele M, Zeddies J (1994) Economic aspects of breeding for yield and quality traits in forage maize. Plant Breeding 112 , 110-119 
Van Keulen H, van der Meer H, de Boer IJM (1996). Nutrient balances of livestock production systems in the Netherlands. WIAS Symposium, Utilization of Local Feed Resources by Dairy Cattle, Wageningen, EAAP Publication No 84, 3-18

Van der Woude K (1996) La digestibilité, facteur déterminant pour la sélection maïs ensilage. Symposium on Silage Maize (AGPM, IE, Inra, ITCF), Nantes, 17-18 September 1996, 445-446

Vattikonda MR, Hunter RB (1982) Comparison of grain yield and whole plant silage production of recommended corn hybrids. Can J Plant Sci 63, 601609

Verbic J, Stekar JMA, Resnik-Cepon M (1995) Rumen degradation characteristics and fibre composition of various morphological parts of different maize hybrids and possible consequence for breeding. Anim Feed Sci Technol 54, 133-148

Vignols F, Rigau J, Torres MA, Capellades M, Puigdomènech $P$ (1995) The brown midrib 3 (bm3) mutation in maize occurs in the gene encoding caffeic acid O-methyltransferase. Plant Cell 7, 407-416

Wolf DP, Coors JG, Albrecht KA, Undersander DJ, Carter PR (1993) Forage quality of maize genotypes selected for extreme fiber concentrations. Crop Sci $33,1353-1359$

Wricke G (1962) Uber eine Methode zur Erfassung der ökologischen Streubreite in Feldversuchen. Zeitschrift für Pflanzenzüchtung 47, 92-96 